Article

\title{
Aesthetic Theory and the Philosophy of Nature
}

\author{
Said Mikki
}

check for updates

Citation: Mikki, S. Aesthetic Theory and the Philosophy of Nature. Philosophies 2021, 6, 56. https:// doi.org/10.3390/philosophies6030056

Academic Editors: Marcin J.

Schroeder and Gordana

Dodig-Crnkovic

Received: 4 May 2021

Accepted: 23 June 2021

Published: 6 July 2021

Publisher's Note: MDPI stays neutral with regard to jurisdictional claims in published maps and institutional affiliations.

Copyright: (C) 2021 by the authors Licensee MDPI, Basel, Switzerland. This article is an open access article distributed under the terms and conditions of the Creative Commons Attribution (CC BY) license (https:// creativecommons.org/licenses/by/ $4.0 /)$.
International Campus, Zhejiang University/University of Illinois at Urbana-Campaign (ZJU-UIUC) Institute, Haining 314400, China; mikkisaid@intl.zju.edu.cn or said.m.mikki@gmail.com

\begin{abstract}
We investigate the fundamental relationship between philosophical aesthetics and the philosophy of nature, arguing for a position in which the latter encompasses the former. Two traditions are set against each other, one is natural aesthetics, whose covering philosophy is Idealism, and the other is the aesthetics of nature, the position defended in this article, with the general program of a comprehensive philosophy of nature as its covering theory. Our approach is philosophical, operating within the framework of the ontology of the process of the production of art, inspired especially by the views of Antonin Artaud, Nietzsche, Heidegger, Bakhtin, Deleuze, and Guattari. We interrogate Dilthey and Worringer while outlining an ontology of art based on the production of nonhuman images and a nonpersonal experiential field of nature.
\end{abstract}

Keywords: Philosophical aesthetics; philosophy of nature; ontology of art; Antonin Artaud; Nietzsche; expressionism; idealism

\section{Introduction}

Let us ponder the transition from Aristotle [1], on one side, to Artaud [2], Eisenstein [3-6], Bakhtin [7-11], on another, and then back. The distance traversed in between spans the vast majority of some of the best aesthetic theories available so far. In effect, Artaud had called for a return to nature where art is expressive of natural movements as such, i.e., a disclosure or unconcealment of the fundamental dynamics of events and happenings in the real world. With Artaud, there is no real interest in dealing with the term 'external world' if by the latter we understand the naive objective material world. Instead, in the Artaudian version of aesthetic theory we encounter a full-blooded revolt against the authoritarian strictures of Idealism and its new Gods: Man, Subject, Ego-consciousness, the Signifier. ${ }^{1}$ Note that Artaud was by no means ignorant of the externalization of experience in material forms, but he consistently rejected a dualistic ontology comprised of mind/body, or somatic/psychological structures working in parallel, preferring instead a fully fledged materialist ontology based on bodies and their coupling and mutual interactions, where consciousness is seen as a generated natural product created from within the highly abstract system of bodily relations. It is mainly due to Deleuze and Guattari that such understanding of Artaud's materialism has become widely known in the last three decades, see in particular Capitalism and Schizophrenia [21,22]. Therefore, if it is possible to associate 'natural aesthetics' with Idealism (including its inverted version of naive materialism), ${ }^{2}$ and 'aesthetics of nature' with Artaud, then the natural question to ask here is that about the real philosophical difference between the two views of aesthetic theory. Explicating a possible answer to this question is the main subject of this article.

Throughout the "low and dishonest decade"3 of the 1930s, Antonin Artaud had stood up to the prevailing order and composed his great For the Theatre and its Double [2], where he boldly announced that the goal of theatre (or art in general) is not enforcing opinions expressed by words (ideology), but the living again of the real as corporeal, that is, nature in its true formal manifestation: Bodies in interaction with each others. The emphasis on the physicality of the flesh is part of the new program's desire to redirect art toward its home abode: Nature. According to Artaud, performance on the stage must avoid 
the intentional broadcasting of ready-made ideas and propaganda lines, moving instead toward the reenactment of natural processes by the production of incorporeal expressions while playing and manipulating purely corporeal elements. And that is why we can call such approach to the philosophy of art the aesthetics of nature.

Similarly, and independently of Artaud, who worked completely alone, other thinkers had advanced complex and radical theories of the aesthetics of nature, most prominently Mikhail Bakhtin [7-11], Sergei Eisenstein [3-6], Nietzsche [26-31], and Fernando Pessoa [32]. A detailed engagement with their corresponding thinking about the connection between art and nature will be taken up by the author in future publications. ${ }^{4}$ We add here that in spite of the extreme diversity of the technical contents of their philosophies of art, they all share with Artaud a common characteristic, which is the attempt to demonstrate that the artistic process is not a commentary by humans on nature, but is the living through of the natural process as such, where "living" does not signify "lived experience", but the re-actualization of the virtual by opening up to outside fluxes and lines of flights and possibilities. Felix Guattari, an avid reader of both Artaud and Bakhtin, captured this spirit extremely well in some of his best books [37,38].

For our immediate purposes in this article, we focus on Artaud as a representative of the aesthetics of nature. We propose an ontology for art based on the concept of nonhuman experiential field in nature, which is connected with another idea, that of the nonpersonalistic image. The ontological model is outlined and developed in parallel with a critical reexamination of the conventional approaches often adopted and practiced within the theoretical framework of Idealism. The main proponents of natural aesthetics are the group of philosophers and artists associated with Idealism. We interrogate the idealistic position through a dialogue with Dilthey and Worringer, two key figure in the transition from the modernism of the late nineteenth century to the incipient postmodernism of the early twentieth century. The reason we choose those particular thinkers, say Schiller, Dilthey, and Worringer, to represent the background against which the aesthetics of nature of Artaud (and others) will emerge, should become more evident in the respective locations where their work is discussed within this article. For now, we mention that both Schiller and Worringer can be considered special transitional figures in the history of aesthetic theory. Schiller was no Kant, so his work is not the canonical text of Idealist aesthetic theory, yet he was strongly influenced by Kantian philosophy, practically like every member of the group of thinkers and artists directly or indirectly affiliated with Romanticism and German Idealism [39-41], while pushing his own art and aesthetic theories toward the extremes of a position embracing both the philosophy of nature and transcendental philosophy. The same can be said regarding Goethe, who even went further than Schiller in this regard. 5 Similarly, Dilthey's and Worringer's views enjoy the paradoxical status of being in a state of perpetual "productive and rich ambiguity". For example, Dilthey is a clear transitional figure working in late nineteenth century, early twentieth century. Starting from Schleiermacher's hermeneutics [42], he moved into history [43], sociology [44], discovered Husserl's phenomenology, especially Logical Investigations [45,46], published around 1900, which Dilthey would permanently integrate into his fundamental researches on the human sciences and aesthetic theory [41]. His concept of the lifeworld is neither fully Idealistic nor completely naturalistic. Wilhelm Worringer, on the other hand, is the product of the philosophy of Georg Simmel. The latter, like Dilthey, also bridged the nineteenth and twentieth centuries by proposing an original sociological and metaphysical body of work, not by way of Husserlian phenomenology, but via a unique and original synthesis of Marx and Nietzsche, on one side, [47-49], and, on the other side, by inventing a novel fundamental ontology based on a post-idealistic, non-biologistic concept of Life [50] that, according to Gadamer [41], had strongly influenced the early Heidegger. As we can see then, those thinkers, namely Schiller, Goethe, Dilthey, and Worringer, present an excellent unorthodox frame of reference for developing an alternative to idealism and its aesthetic theory, but this time while fully based on the philosophy of nature, not the Cartesian-Kantian-Hegelian subject. From this perspective, Worringer becomes a key figure 
who seems to able in particular to illuminate the complex transition from modernism to postmodernism, e.g., via his role in shaping the thinking of postmodernists such as Deleuze, Guattari, and Baudrillard.

This article is structured as follows. Following this general introduction of the present Section 1, which defined our main problem and provided motivations and general remarks on the scope and methodology of this work, we start with our first examination of the relation between natural aesthetics and the aesthetics of nature in Section 2, where Schiller's work is deployed as a point of first entry into the view of the former school of thought. This is followed in Section 3 by our first formulation of the position of the aesthetics of nature, where we briefly outline an ontology for the process of the production of the artwork inspired by the philosophy of nature and based on the concept of a nonpersonal image and experiential field in nature. In Section 4, a criticism of Idealism and natural aesthetics is provided in order to motivate the transition to an alternative theory of the process of art production. As a preparation for this transition, the overall position of Goethe is very quickly examined in Section 5 . The central ideas of the program of the aesthetics of nature are outlined and analyzed in Section 6, where we choose Artaud's work as the central frame of reference. We then return to natural aesthetics in Section 7 through a careful examination of Worringer's influential work on expressionism and how it relates to Idealism and naturalism. Due to its emerging importance and potential overalp with the aesthetics of nature, the subject of posthumanism is very briefly taken up in the small Section 8 in order to demarcate some of our ontological themes, such as the concept of nonhuman images and the post-human society, from parallel relevant, or not directly related, concepts found today in the various currents of mainstream posthumanist thinking. Finally, we end up with conclusions.

\section{Schiller's Law}

The human lifeworld is often set against an externalized, materialistic, "nonhuman" world. The latter is what is usually understood by the generic concept of Nature, which is based on the Greek term physis [51]. However, this simplistic picture, though accurate at the macroscopic level of the structure of the history of ideas, is often contested in more specific formulations. For instance, see Heidegger's critique of the concept of nature as understood by both antiquity (Platonism and Aristotle) [52-54] and modern science [14,23]. Yet, even before Heidegger, Neoplatonism had approached Nature in a manner more fundamental than several previous post-Socratic philosophers, see Plotinus [55] and Proclus [56] as outstanding examples of the revival of the philosophy of nature in Late Antiquity. ${ }^{6}$ While one may always find scattered writings on aesthetic theory, or general reflections on art, between Aristotle and Kant, we will here jump directly to the modern period, that usually taken as the one inaugurated by Descartes's work, which introduced the Ego, or roughly the Cartesian subject, into the heart of the discourses of natural philosophy, metaphysics, and aesthetics [40]. Within this general purview, treated generically in our article under the rubric of Idealism, Nature is always understood as that structure defined with respect to the human pole of experience, which is the more fundamental vantagepoint according to mainstream Idealism, especially the point of view associated with the Cartesian Subject. ${ }^{7}$

In such modern period, there is the basic question regarding the relation between the human and nonhuman, the latter defined as the "objective" - or simply "nonsubjective" world. In the aftermath of Kant's main work, especially around the turn of the nineteenth century, the question has been approached in a particularly fundamental manner via several Romantic and German Idealist thinkers. It appears that art and nature are essentially related to each other, though not in the peculiar way found in German Idealism. Let us recall Dilthey's expression of what he called Schiller law:

I shall designate by Schiller's law the thesis that the aesthetic process can either discern a liveliness of feeling in outer form and thus enliven what is visible, or make life visible in outer form and thus give life form. This law thus involves the constant translation of lived experience into form and form into lived experience. ${ }^{8}$ 
In our opinion, Schiller's law roughly presents the nucleus of what could be approximately described as the framework of post-Aristotelian aesthetic theory. Note that this latter theory does not consider the classic Aristotelian text Poetics [1] as the principal bible for the post-Cartesian aesthetic era. In fact, both Spanish and English dramatists viewed Greek tragedy as a bad model for expressing the needs of the new bourgeoisie world, with its commercialism and anti-religious sensibilities. Regardless of the fact that both Goethe and Schiller were delighted to discover the eventual agreement between their own aesthetic theories and Aristotle's, the fact remains that the rigorous theoretical formulation of the problem, as compactly represented by the Diltheyian Schiller's law above, is a departure from the Aristotelian style of thinking. The German theory takes it for granted that form is by default dead. Form is the "soul" of nature, but nature is defined-following idealism - as that which is not human, i.e., the external or outer world per se. Everything that is not "me" or "us" belongs to the natural order of beings. It follows then that formconceived here on the model of geometric (Euclidean) figures-is necessarily passive and static. On the other hand, life belongs to "us" human beings, and therefore is necessarily correlated with structures that are of the order type of the inner, interior, internal, and so on. The dialectic of life and nature, the inner and the outer, makes its appearance here, and Hegel [69] — following earlier formulations by Schilling [72] and the Schlegels [39] will take this "dynamic duality" into the most extreme level reached by pre-Husserlian Kantianism, that of the logic of the Absolute [70].

Schiller's law states that the essence of art resides in bringing this inner feature of dynamic life (the Lifeforce) into the "dead externalism" of form: Art consists of merging the lively, as found within experience, with the formal dryness of the outside. It is not difficult then to see that, according to this new formulation, the following is the case: that which lies within is to be taken as the privileged pole: The human subject is conceived here as the ultimate goal of the art process (idealism, Romanticism, phenomenology, existentialism, etc). Nature would acquire an aesthetic significance only by manifesting herself to the observer as an external totality infused with the human value of becoming $a$ life for us. ${ }^{9}$

The key term 'visibility' enjoys a prominent position in the German aesthetic theories of Goethe, Schiller, the Schlegels, Hegel, and others [39], indicating how seeing, that central organ of Kantianism [23], is still the fundamental ontological process [92]. Art is here understood as an apparatus or process capable of altering the mode of visibility of "dead objects" by transforming them into carriers of human values. Within the overall theoretical program of Idealism, we may view the creation of artwork as the alteration of perspectives, a change in the device we employ to evaluate entities and things. A sculpture transforms into an artwork by investing its passive matter with aesthetic value. A perfect analogy with the new economic order of mechanized mass production in the emerging global industrialism of the late nineteenth century [93], for Marx would theorize that production transfers labour value to the "dead object", hence enlivening it-making it a commodity [94,95]. Similarly, in idealism, artworks and commodities are products of the assembly lines of modern time [93]: Life is injected into dead matter by skilled craft, a metamorphosis of the dead into vibrancy and livelihood [96,97].

But if nature and life are one and the same, then Schiller's law becomes an immediate triviality. What is the point of art if it strives to reaffirm the known and obvious? It is for this reason that the philosophy of nature cannot accept the pre-Artuad, pre-Nietzsche contribution to aesthetic theory as final. The failure of German Idealism in this regard can be approached from two different but related perspectives. First, the ontological perspective, where recognizing the identity of form and life leads us to question the originality of Schiller's law. The second perspective is political, which relates to the Marxian analysis of the way in which idealism had flirted with art in order to integrate the production of artworks with the firmly established capitalist regime, subsuming the "spiritual" inner life of the individual, as manifested through artistic expression, to the material laws of the economy, hence ending up forcing culture to become a determined (or dominated) superstrata in society [98]. It should be noted here that the Marxian perspective is not 
necessarily Marxist, and that in the philosophy of nature what should be understood by technical terms like matter and form is very different from the Hegelian concepts so prevalent in orthodox Western Marxism, e.g., Lukacs [99], Adorno [100,101], and Marcuse [102]. By allying itself with Hegel's Logic [70], Western Marxism relapsed into Kantianism and missed a fundamental insight brought by Marx's work: the critique of both idealism and capitalism in one and the same book, Capital $[68,98]$.

The need to search for organic connections between art and nature is not a retreat into inhuman modes of expressions. What is nonhuman is not necessarily inhumane. The new aesthetics of nature is neither pro-Rousseau nor anti-Rousseau, and the model after the poet-as-Goethe and his characteristic relation to nature is not really a direct concern for us here. By declaring Schiller's law a triviality, the intention is to reorient art toward the nexus of natural events as singularities impregnated in the real world [81] while generating the flux of experience, the very inner flesh of Nature's lifeworld itself. The concepts of living and lived experience have been initially developed by the introspective techniques inaugurated by Augustine, then rediscovered by Descartes and Fichte, but always while focusing on the interior space of the person, the selfworld. In Idealism, it is the human psyche as a model [16,103], a universe populated by thousands of small little shattered selves, each associated with desires and pleasures, connecting instinctive drives with culturally-acquired habits and social motifs, all marching with Reason in unison. ${ }^{10}$

\section{The Nonhuman Experiential Field of Nature}

The sum total of all these atomic happenings taking place in the depths of the selferuptions of the soul and the waning of will, the adumbration of feeling tones and harmony, dark intimate moments of visions-all such inner inflections have been baptized, in the hands of past thinkers and artists, by the generic term 'experience' [41,65,71,105]. Idealism, then, reemerges into the scene, again. The concept of experience is strongly entangled with ideology [106], no doubt, for how do we know that the selfworld is the ultimate locus of experience [65]? Isn't this, again, an ego-centred attitude motivated by the inherited techniques of self-introspection? The meaning of the self is not disclosed by experience: It is the self that is generated from within a nonpersonal experience in nature, manifested as a field of affects; empirical persons are simply "objects" tapped into this universal field. Nature is too rich and broad a concept to be exhausted by reductionism or atomism [107], but experience is one of its fundamental modes of existence. Even though we find it utterly impossible to define nature using "pschyological" terms, it is not too much an oversimplification to state that nature becomes through experience. Or, in other words, one may say that there has been a world since, from the beginning, there was something like an experiential field of Nature (before even the emergence of consciousness). The various physiological and mechanical effects preserved inside the enclosing bio-surface of the organism, forming the biological self, are in direct communication and interaction with this global field of Nature [81]. Self excitations of the experiential field lead to the genesis of the ego, the self, the person, and so on. But overall there remains a deeper significance than that, for the enlivening of the self through experience generates values, signs, meaning-wholes, hence giving rise to connective semiotic networks radiating away from the enclosing surface of the individual [108,109].

Within the cosmic program of the philosophy of nature, we define art as the enactment of a phenomenological description of this experiential field. As such, art naturally first strives for communication. To accomplish that, it gets entangled right from the beginning with the reproduction of meaningful blocks of signs and symbols. This is why there is no art without a theory of meaning, and no meaning in independence of a metaphysics of nonpersonal experience. During the technical process of the production of the artwork, Nature recedes to the background, functioning only in a metaphorical manner, while the real process of living through experience is left for the private imagination and the creative virtuosity of the artist as a finite self. Therefore, a tension inevitably arises between the self-pole and the nonpersonal experiential field during the process of recording lived experiences by 
the ego-consciousness and the subsequent production of meaning antecedent to forming the artwork. There appears to be a conflict in nature between the personal self and the nonpersonal field, but the entire difficulty of artistic creation hinges on devising stable methods capable of generating a temporary resolution in terms of signs emitted from the individual through the work of art.

How does the artist approach experience then? Not introspectively, like the comic figure of a person "psychoanalyzing" his own self in order to seize on fruitful materials for productive work; and there is certainly no comparison here with the solemn vocation administered by Aristotelianism centered on imitation [1], which nowadays appears to resurface in some of the aesthetic theories of mimesis [110]. Experience is approached artistically only through the medium of imagination, that is, the process of the production of lived images. Once an image is produced, it enters into the surrounding nonpersonal experiential field of Nature and stays there. An image is to be sharply contrasted with the idealistic concept of fantasy ${ }^{11}$ by the fact that the former is objective and real, while the latter is subjective (but still real ${ }^{12}$ ). Fantasy can be induced by drugs [21] or ideology [106], while begetting images require a concentrated mental effort akin to creation. Average men and women engage with pre-fabricated images distributed into society through the agencies of mass culture and media [116,117]. A "propaganda engineer" is a person responsible of designing and building various types of images for wide circulation and consumption under the hegemony of the dominant ideological field, and it is such kind of artificially created images that is usually used up by typical persons [118,119]. On the other hand, artists possess such a rich psychological constitution, and enough intellectual facility, allowing them to create their own internal images. But while those images are created privately, art re-injects them into the existing rhizomes of social and cultural fields, ensuring that the interior (self) is safely connected with the exterior (world) through a semantically functioning circuit of exchange. Here, communication emanates from the self-pole of the creative person toward nonpersonal experiential fields, not necessarily in the direction of other persons. True art transcends the ideological field by striving to connect with the ubiquitous field of natural experience, cutting through the existing web of power relations dictated by the dominant ideology. This is why artistic imagination is fully objective when it gives birth to images belonging to the nonpersonal world of nature. In comparison, fantasy is a relatively local subjective phenomenon occurring only within the boundaries of the ego-consciousness pole of private individuals, where the latter are busy consuming pre-made iconic and symbolic imageries handed down to them from media and mass culture institutions $[48,118]$.

Artistic creation is the production of new images embodied in a material form. Therefore, the antecedent stage involving the artist's pure phenomenological description of lived expedience is not by itself sufficient for completing the task. After generating an internal image, the result must be translated into a communicable form, and this in turn requires molding the imageries thus attained into a concrete material shape: music, sculpture, painting, performed act, literary text, and so on. An artwork is always a concrete object laden with meaning, waiting to be transmitted, in one way or another, to some potential audience, we don't know exactly who, but the absolute ability to achieve the successful transfer of a signifying essence to other receivers is fundamental, even if this receiver happens to be one and only one individual: the artist himself. Art and communicability are therefore indissolubly linked, and Bakhtin was profoundly right when he theorized about the fundamental notion of the answerability of the work of art and its various ontological ramifications [11].

We must, however, be careful to avoid inviting any subjective element into our ontological analysis as developed up to this point. When we speak about the internal image, this is not to be understood as a "representation" generated in the interior world of the artist's psyche. The latter is certainly involved, at least at the empirical level of the process; but from the ontological (fundamental and applied) perspective, an internal image is as "objective" and real as an "external" image, which is principally due to both ontological 
structures being one and the same primary matter, or sense-hyle, but expressed differently in the two situations. In one case, the image is presented to the self-pole through materials largely derived from sensations and sense impressions [120], the basic building blocks of the psychic lifeworld (selfworld) [121]. In the other case, the internal image is converted into a material representation using physical or linguistic signs or other means [108,109,122]. The formal essence of the image is generated only once (in the artist's imagination), but once released, it can live independent lives in unlimited number of material expressions. An image is essentially indestructible. This explains the apparent paradox about the contradiction between the concrete material realization of the completed artwork and the universality of the formal essence of any artistic creation. A resolution can be found once we realize that the so-called "completed artwork" is in reality one material expression among infinitely possible others. The artwork is a physical or semiotic material realization of an image that happened to be generated initially inside the artist's imagination, the image itself becoming-once created-an eternal object joining the inhabitants of the experiential field of nature. Therefore, a singular artwork remains laden with "universal essence", though surely not "universal" pace idealism or Kantianism, but rather in the specifically ontological understanding we prefer to deploy in the philosophy of nature.

The underlying matter of the artwork is the image. In nature's experiential field, the image is permanent. This eternal object may be manifested in myriad expressive forms, depending on the contextual nexus of these social fields in the topological neighborhood, or the "vicinity", of the image. The same image may be expressed in music, poetry, drama, painting, etc, but even if new media for art production are to be invented, it is still possible to express the very same image by the ontological language of image-forms. In other words, the process of making an image become concretely embodied in the artwork is merely a technical problem. But sometimes a profound image can be expressed in one medium only, like music, where afterwards it is hard to find a proper material expression in other languages. ${ }^{13}$

\section{Image vs. Impression: A Critique of Idealist Aesthetic Theories}

An image, as understood in the aesthetics of nature, should not to be confused with the psychological concept created by the British empiricists Locke [134], Hume [120], Berkeley [135], and their continuation in the German schools of Kant, Herder, Goethe, Schiller, Lessing, Schlegel, Wundt, Helmholtz, and Dilthey [43,71,136-140]. In all such quarters, one finds the newly founded domain of aesthetics constantly conflated with the systematic study of psychic impressions and feeling-tones, personalistically defined, while approached through the application of techniques and methods derived from perception and introspection. The proclamation of the scientificity of the emerging discipline, for example as manifested by the researches of Helmholtz on physical acoustics and musical aesthetics [141], was certainly among the main factors responsible for the adoption of such psychological approach to the topic of art reception, which was equated, at least since Kant, with "sensation". ${ }^{14}$ To sense the beautiful in an artwork is therefore a special kind of feeling to be "rigourously" distinguished from other forms of impressions crowding the inner sphere of the person. Now, while it is true that art is an exclusively "human" domain of creativity, the ego-pole serves only as a point of departure (creation) and a spot for termination (reception) of artworks without the need to restrict the actual process of communication to the psychic level. In other words, the person is contingent on putting the internally generated image in a form amenable to understanding within existing social and cultural fields. But in the philosophy of nature, we find that the image as such-its laws of formation and production, its manner of communicability and exchange, its mode of movement and transfer, and finally its ability to interact with other ego-poles, that is, all such natural modulations of the functional role played by the image-form - is not merely a psychological structure, but, in fact, a fully fledged ontological process in and through.

Let us try to very briefly review how this psychological turn in aesthetic theory has unfolded in modern times. Starting with Kant [136], German Idealism had attempted 
to steer aesthetics away from the "metaphysical" Leibniz by declaring the study of art a scientific and systematic endeavour, which is expected to be carried out with utmost care and using the most rigorous methods [69]. This counterattack by Kantianism relied on a selfconscious deployment of various readily available Cartesian methodological apparatuses exploited in order to undermine the essential advance made by Leibniz [148] over Descartes in this area of research. Everywhere, and up to the present day, the idealistic approach to art continues to concentrate on how a person perceives the sings emitted by the artwork, whether within a context of interpretation (hermeneutics $[41,42,71]$ ) or sensation (scientific aesthetics [140-142]), where, in any case, the net outcome is a reduction of the problematic of art production and consumption to the various overlapping personal "bubble-spheres" of human players [149] acting within a social field. Even Western Marxism [145,146,150], with its characteristic concern for the literary and the beautiful, has not been able to fully appreciate the ontological irrelevance of the human dimension in the process of artistic creation and communication. It is mainly starting with Nietzsche $[13,26,30,151]$ and Artaud [2] that the heavy hands of the doctrine of ego-consciousness (Cartesianism, Kantianism, Hegelianism, Romanticism, orthodox Marxism, Neo-Kantianism) began to loosen their grip on the mainstream ideology of the aesthetic as administered within the tradition of idealism, virtually the only direction of investigation open to inquiry in the academic wold up to that point.

We will continue to explore Idealism through the lens of the writings of ambiguous intellectual figures such as Dilthey, who are literally living "on that critical edge of modernity" where modernism will soon transform into postmodernism. In such places, one finds classicism, ancient philosophy, Kantianism, hermeneutics, psychologism, neo-Kantianism, and phenomenology all intermixed in highly complex forms, yet while still expressing a distinct streak of Idealism. Within the parameters of the world-historical reformulation of Idealism espoused by Dilthey, he defined the scope of "rational aesthetics", or the scientific approach to art, by the following, essentially complete, descriptive passage:

Rationalist aesthetics conceives of beauty as a manifestation of the logical in the sensuous and of art as a visible presentation of the harmonious nexus of the world. In his sensuous intuition, the artist obtains an obscure but intensely felt awareness of this nexus. As there is but a single world-nexus, the sensuous relationships that exist within it must ultimately be formulated in one principle. Natural beauty and artistic beauty express this nexus in their respective languages. Even the most spontaneous expression of imagination is subject to rules. Such rules are found in harmonics and metrics; they are operative in the flow of a line, in the formation of a figure, and in the ornamentation produced by the architect and the artist. The taste of a poet is developed as an embodiment of such rules. Unity of action and precepts deriving from it govern drama. And all these rules are grounded ultimately in the rational order of the universe. ${ }^{15}$

Here we find the infamous presupposed isomorphism between the world and the mind. The "logical", therefore, expressed in and through the "sensuous". Within this framework, aesthetics is essentially the study of the laws governing the production and combination of sensations. Harmony in sensations and the rational order of the universe are unified in one and the same intellectual and artistic discourse. Idealism sees the essence of the cosmos reflected in the person contemplating nature.

Although Kantians revere natural beauty, including the pre-Kant Rousseau and the post-Kant Goethe, expending great efforts to extol the uniqueness of the position of the physical and living worlds with respect to the observer, still in Idealism it is ultimately the human factor, or, philosophically speaking, the perceiving subject, to whom the entire process of nature is referred. Natural beauty is equated with artistic beauty, hence the return to a modern interpretation of Aristotle in terms of the Cartesian subject, the latter is now viewed as "imitating" the universal ideal of reason as manifested in the natural world. The cosmos is ordered according to the mental a priori conceptions of our mind. If there is a beauty "out there", it is because the internal image, generated in and through the 
process of the perception of a natural entity, reflects precisely those harmonious relations put into the very same "object" itself, which had been already created after the entity through the act of perception (the transcendental reduction). In Kantianism, the movement from "something unknown" (the entity, or Object X) to the "perceived something" (object) exhausts experience. Experience here becomes lived experience, while any nonpersonal experience is rejected as a relic of the pre-scientific metaphysics of the ancients, including even modernizers like Leibniz and Spinoza. This "new aesthetics" is an unashamed, fully fledged Cartesianism: the study of art is reduced to the search for "rules" and "natural laws" governing the dynamics of the "sensations of the heart" according to the dicta of Universal Reason. There is then a double reduction at the heart of idealist aesthetic theory. First, a reduction of the matter of the beautiful into ultimate sensations in the human subject forming the basic building blocks of the aesthetic lived experience. Second, a reduction of these sensuous "aesthetic atoms discoursing on the world" into the rational disciplining of the perceived by positing strict universal rules and laws behaving according to the strictures of Reason and the Beautiful Soul. The Beautiful is that in nature which is discerned by Taste. In Kantianism, Nature is subjugated to Taste [136].

\section{Interlude: Goethe and the Process of Nature}

An admirer of Kant and a self-proclaimed "idealist" like Goethe, however, proceeded differently. With this world genius, we don't meet the obligatory incentives of Kantian aesthetics and its authoritarian prescriptive rules of discourse, but rather the creative process itself, which, in Goethe's case, is exclusively reduced to the embodiment of the collective mind or unconscious in the contingent body and person of the artist-genius, hence directing the real focus of inquiry. In our interpretation of the Goethean process of becoming-artist, art is not about sensations or pleasure, whether being interested or disinterested. True art, or at least its ontological core as a process of genesis, has much less to do with subjective feelings, while individual perception should be treated as secondary, relegated to the merely biographical. Nature and art become one in the process of production: The production of images (art), the production of concepts (science), the production of ideas (philosophy), the production of objects (perception), the production of organisms (ontogenesis), the production of desire (psychogenesis), and so on. The natural process and the artistic process are not two parallel developments, one belonging to a contemplating human mind, while the other to a dead, passive "nature". Rather it is the other way around: feelings and aesthetic pleasures and lived memories are the redundant and secondary part of the entire story: With Goethe, it is Nature that is alive and productive, while the human pole and its correlate, the ego-consciousness, are relegated into the cosmic process of becoming we find in the Whiteheadian concept of nature [83,107].

In fact, Bakhtin had already noted that this cosmic concept of nature was fully developed in Goethe [10]. ${ }^{16}$ This attitude toward linking the philosophy of nature and art, as exemplified in the person and work of Goethe, has survived into the early twentieth century, especially in the thought of our interlocutor Dilthey, who deeply admired the Goethean system of the world, probably more than any other work of art. In a beautiful passage, Dilthey summarized this Spinozist worldview of Goethe in the following manner:

.. Goethe's poetic imagination unlocked the mystery of nature and art. Because Goethe's efforts to intuit nature were akin to the process of artistic productivity, his experience of the creative power of his own imagination was at the same time a disclosure of the power of nature itself. He regarded nature as a purposive power, governed by laws, which express itself in metamorphosis, intensification, architectonic of typical forms, and the harmony of the whole. Consequently, art was for him the highest manifestation of the workings of nature. ${ }^{17}$

Therefore, scientific inquries into nature through postmodern mathematics and artistic creation are not set in opposition to each other, but are manifested by two complementary aspects of a unitary intellectual endeavour aspiring to achieve a profound understanding of nature and life. This is not a return to English Romanticism or early nineteenth-century 
German thinking. We are fully aware of the deep difficulties inherent in any non-empirical approach to nature, especially the problematic aspects of Naturphilosophie as exemplified by the latter's inevitable entanglement with one form of Cartesianism or another. There is also no royal way back to the Greeks as envisioned by Wagner [152], dreamed by Nietzsche [26], and indefatigably analyzed by Heidegger (in almost all of his books). The most effective path remaining open to the philosopher, we believe, is the one chosen by Artaud: To be both the theorist/aesthetician and the artist: reflecting on art by first creating new art forms, then constructing an original aesthetic theory not by way of commentary and amassing observations and notes, but by working directly at the ontological level of the metaphysics of the nature-art complex.

\section{Nature and Art, Bodies and Schizophrenia: Sweet Artaud}

In order to see, hear, and feel an artistic experience, theories about "the rational depiction of nature", or the bourgeoisie disinterested pleasure, must be bracketed out and suspended [37,58,96,131]. In fact, it is schizophrenia as a productive field—in both the political and artistic sense-what counts most when it comes to experiencing and recording new modes of creativity within modern culture [19-21]. Dilthey's account of the poetic experience [71] remains tainted by idealism, whose machinations, we believe, he was unable to break free from, even until the end of his distinguished intellectual career, in spite of the fact that Kantian standard aesthetics was not the major focal point in the oeuvre of this otherwise remarkable writer.

Let us start by asking the following question: Why should "joy" be ascribed to the art vocation? When the Enlightenment turned toward the aesthetic experience [39], everything was planned within a large-scale production scheme intended to supply the crowds with mass entertainment $[48,93,116,118]$. Although this task was already present in the Greek world, where tragedy, inseparable of its theatrical public staging, served as one of the fundamental communication channels connecting intellectuals with the "people" [153], the modern period has been consistently undermining the true relationship between the art experience as creative production on one side, and its corresponding consumption by the receiver. We are currently entering into these strange times where everything on the stage is premeditated and pre-orchestrated by meticulous calculations performed by the "creative art director" (the modern art "executive"), whose sole purpose in many cases appears to be addressing the crude and vulgar instincts of art mass consumers $[118,147]$. Within this overall political framework, genuine interest in what really takes place inside the productive genius' mind would naturally decline, shifting into neighboring disciplines like psychology or sociology. If art is all about the production of singular images nowhere to be found in mass culture, then the "state of mind" of the actual producer in this supreme process will itself become an essential ingredient of the created image as such.

This is why when reading the private papers of great artists and thinkers, we just can't help but assume that the writing process itself was part of an overall plan or mission pursued unconsciously by a collective (nonpersonal) mind irreducible to the concrete empirical ego of the artist in question. In a letter addressed to his doctor, Artaud described his personal feeling-tones using the following extraordinary sentences:

Something which has almost disappeared from the field of my observation and which no longer characterizes my condition is the impression of incredible fatigue, of total exhaustion, an exhaustion which seems to undermine the resistance, the muscular coordination of the organism on all levels and in all senses. And this sensation of monstrous, horrible fatigue, this vast, extraordinary pressure on the top of the skull and the back of the neck, a pressure whose force and whose volume, seemingly, is so great that it feels like a weight of the world on one's shoulders, is accompanied by one knows not what cosmic emotion, is combined with the tactile sensitivity, the vast feel of interstellar space, and the proof of this is that when I am lying in bed the sensation, far from disappearing, grows worse, is transformed into an impression of painful emptiness, operating magnetically, 
which presses on the limbs and the whole length of the spinal column and surrounds the pelvis. ${ }^{18}$

Everything is described with a graphic, quasi-photographic prose that is both vivid, yet at the same time mechanical, anatomical, and scholarly, the masterful blending of the ugly with the lively being one of the key features of the beastly in the Artaud Universe.

There is no "beautiful soul" to be found here [58]. Like Nietzsche before and the subsequent Deleuze, the grandiose "duty of the genius" as a "responsible" figure in modern capitalist society striving to establish a balance between industrialism on one side, while keeping aflame the spiritual secular sphere of the post-medieval order on the other side, is ridiculed and rejected by the art theorist. We are not dwelling in the interior introspective world of the subjective artist exploring his ego (young Joyce), but rather living up the crushing, suffocating, and intolerable birth of an authentic (ontological) image ejected into the world with unbearable pain and agony. Pain is an element of desire. Nonpersonal desire is the transcendental field of creative art production. It was Nietzsche [31] who first came up with this formula and Artaud rediscovered it by undergoing a process of becoming-schizo just after Jung himself had gone into the same metamorphosis [154-156]. Nature herself is at work in the body of Artaud's mind where the mental becomes pure primary matter: an infinite concentration of sheer productive virtuality. The inextricable link between pain and productivity has only a passing resemblance to the classical agony of the great artist meticulously described by idealist aestheticians and art historians. There is nothing sublime or otherworldly or magisterial about the forehead of the master or his divine eyes; only flows of shit, urine, blood, flesh, sperm, clay, mud, lava, are what populate the schizo's cosmos [21]: it is neither pitiful nor ironic nor even humorous, but absolute de-composition and dis-connection; neither decay nor dissolution, but, like the Heidegger machine, an ontological construction that must first be preceded by destruction [16,52], and what has been dis-connected may be re-wired again in the future [22].

The above graphic Artaudian clinical depiction of the aesthetic experience is followed by a sobering description of the hardcore of the creative process as such, that concerning the eruption of nonhuman images:

When I am in these states, a number of unconscious images persist, they themselves are not sick, but the malady seems to manifest itself the moment an image becomes conscious, however slightly, the moment it is invested with sensibility, emotion, will. As soon as the slightest suggestion of an intellectual desire appears to help some image or idea take a body by taking a form, as soon as one tries to pronounce in a clear and lucid manner any one of those unspoken words which the mind associates endlessly, the disease manifest its presence, its continuity; it is as if the mind needs only decide to enjoy an internal idea or image for this enjoyment to be taken away from it: the spoken image regularly miscarries, and to try to bring this idea or image into the world is even more difficult, and only serves to reveal more flagrantly and more rapidly the lack of continuity, the lack of nervous density which is fundamental to my present personality. ${ }^{19}$

Theoretical psychology, clinical psychology, aesthetics, physiology, ontology, literature, all mixed together and integrated within the singular aspect of viewing and "seeing" the image produced in the interior space of the artist. Sickness comes from consciousness, the moment an unconsciouns image becomes "sensible" (Artaud's Law). Schizos are not always miserable sick people, even when their pain and howling are intolerable, for they signify a state of tension in nature that has reached a limit point following long periods of accumulating exploding materials unconsciously transmitted throughout thousands of years [157-159], inevitably leading to the violent opening up we witness in those crushed persons now fatally experimenting with the bleak destiny of their fractured being [129].

But do we have to reject Artaud the thinker by projecting Artaud the individual as a "patient", a mere philosophical "case study", a representative sample of the prototypical "depressive maniac" popular in post-World War I modernism and post-World War II postmodernism? Not so fast, not now. It is one thing to declare the schizo's private letters a 
documentary evidence indicative of his "morbid state of mind", and a completely different matter to take him up as a model for political activism, mobilizing the body in its pure, nonmoral, anti-bourgeoisie sense through which some artists become effectively the master teachers of humanity at large [160]. There is something so sweet, disarming, and even refreshing about Artaud's private correspondence. The language is pure and simple. The grammar astonishingly transparent. The vocabulary compact and non-pedantic. The flow of the prose mind-blowing: it puts you in the presence of a supreme state of self clarity about the modern world, even when the discourse inaugurated by him is postmetaphysical and not technically demanding. Artaud followed Lawrence [161,162] and Nietzsche [31]. A schizo line of development starts with Nietzsche and passes from Jung through Lawrence to Artaud, this is true, but the three wrote in isolation of each others, unaware of the existence of parallel friendly spheres of contact. Artaud's maturity crystallized in the 1930s, immediately after Lawrence's death in 1930. The Artaud Decade par excellence. We are back to nature and naturalism, not through Aristotelian scholasticism, but via the door of natural life-forms. He digs under the ancient Greeks, Roman Stoics, and non-Western heritages, and overall he always extracts gold. Artaud had done it several times: with Balinese theatre, with Mexican people, with the Cabala and other inherited oriental traditions [2]. His program is cosmic and has nothing to do with an "archaeology of knowledge". It is a cultural excavation not in search for the past, or striving to establish points of connection with an extinguished golden age, but, instead, and similar to Nietzsche's life-long quest [28], Artaud aimed at revitalizing modern culture by putting his finger on the real core of the problem: the political enslavement of artists and their submission to the authoritarianism of bourgeoisie morality and its satellite Kantian ethics. The methods available to him are meagre in power and comprehensiveness but quite efficient: self observation of his diseased body and disintegrating mind on one hand, and recording what is seen in nature outdoor. By combining cultural and clinical empirical data, Artaud was able to study the problem of art from within the medium of art itself. He never needed anybody's help even when material support was essential for keeping him alive for a while. The truth is that a schizo is a monadic singularity reflecting the entire cosmos, a self-subsisting whole encapsulated within superficial enclosures like the skin or the social position of the individual. Since the artist is the productive workshop generating all types of images and molding matter into the form of permanent, detachable structures floating in the experiential field of nature, then, in a certain sense, the art world here has to adapt to the creative genius, and not the other way around (Dilthey himself, the "serene thinker", had already admitted this [71]).

The process of image production undergoes a sharp sociopolitical twist when it becomes a guarantor of the artist's relevance to himself and also the grounding justification for the existence of the art complex in modern culture. We need only pay attention to the way Western theatre remains trapped within the false limits set by the ruling elite, how the counter-attack of the Theatre of Cruelty [163] was designed to shatter the refined sensibilities of the masses accumulated in the long-held European traditional conception of drama as a rational means for the salvation and purification of the spirit $[164,165]$ (the "beautification of the soul" [58]). In fact, drama understood this way is an instrument of domination and guidance leading the exhausted working-class crowds toward the next logical step after long weeks of toil: the intensification of desire and the amplification of the subjective ego at the expense of a true and authentic relationship with nature and life. Working together, Deleuze and Guattari had developed this Lawrentian ethics based on the groundbreaking experimentation of Artaud with his own mental state of being, and the lessons learned from the violent rejection of the authoritarian French society of the Artaudian artistic vision [21,22,125,131]. The schizo lineage comprising Hölderlin, Nietzsche, Lawrence, Artaud, Deleuze, and Guattari: this is the return of art to nature and the coming into being of the natural in the art form. In our interpretation, the key concept in this project is the Image: Productive fields of experience and the experiential field as such playing the role of the effective environing intellectual sphere enveloping the decisive generative act of the individual genius. Schizophrenia is the breakthrough 
of nature into the human individual developed and expanded in and through art forms. These art forms are embodied by free-floating images inhabiting nonpersonal, nonhuman experiential fields signifying that ubiquitous ethico-aesthetic existential tonality expressive of the presence of nature everywhere [37]. An image never lies, for it has neither ego nor consciousness; nor personal ideology nor rational faith.

\section{Naturalism, Abstraction, and Expressionism}

It is probably important now to say more about the doctrine of "naturalism" in art or aesthetics. The position advocated in this article, the aesthetics of nature, has little to do with such canonical naturalistic approach to the perception of artworks and artistic creativity. We are not working with the same "Nature concept" of early nineteenth century romantic poetry and philosophy; nor do we operate with those semantic constraints imposed by late nineteenth-, early twentieth-century aesthetic theories. In the philosophy of nature, the term 'natural' is not to be confused with the banal, pre-Heideggerian, concept of beingin-the-large ("holistic being") that belongs to Occidental metaphysical systems inherited from the pre-Socratics. Within both art and mathematical physics, 'Nature' refers to the virtual horizon formally appropriated — though only provisionally — under the dangerous but unavoidable technical word 'global'. The global emerges from the local, but the local, in turn, is constituted by the global. Nature, in this sense, is not the sum total of entities existing outside a "human subject" or its Hegelian version, the Absolute [166]. By deploying the term 'nature' in our investigations, we suffer the inevitable consequences of an inherently imprecise approximation of the problematic of being. However, our hope for pushing forward along this direction is only a matter of the systematic convenience of carrying through an investigation combining art and mathematics, science and philosophy.

It is impossible at this stage to reduce nature to a "natural mode" by following the Platonic inception of aesthetics $[17,18]$. In his masterful exposition of the history of art, Wilhelm Worringer very carefully emphasized the difference between the technical terms 'imitation' and 'naturalism' [167]. Indeed, it has been erroneously thought—even by philosophers-that imitating a model outside the subject is basically the same thing as being "naturalistic". In fact, imitation is not really part of the overall movement in art history known as naturalism. The latter is a coherent, well-articulated body of concepts, corroborated by a series of attitudes toward the process of artistic creativity, which is way more far reaching in its implications than the traditional and commonplace submission to the instinctive urge to copy a model. Instead, Worringer introduced the dichotomy abstraction/empathy and hoped to demonstrate, by means of a historical analysis, the fundamental irreducibility of the one to the other. As a matter of fact, Worringer's formulation of the problem had theoretically prepared for the contemporaneous event of the twentieth century's rediscovery of abstract art, particularly in painting. What is more important at this stage of our analysis is the emphasis laid by the new formulation on the role played by the psychological process of empathy in explaining the conceptual substructure underlying naturalism. Worringer would rely on this not only to distinguish naturalism from imitation, but also to set naturalism against abstraction. Worringer writes:

We have therefore sought to demonstrate the fact that effacement of the fundamental diversity between mere imitation of nature and naturalism in art is consequent upon the fallacious or one-sided interpretation placed by posterity upon the great epochs of the Antique and the Renaissance. Of the two artistic genera, it is naturalism alone-which did indeed reach its zeniths in the Renaissance and the Antique- that pertains to the sphere of pure art, and therefore naturalism alone is accessible to aesthetic evaluation. Its psychic presupposition, as can be clearly understood, is the process of empathy, for which the object nearest to hand is always the cognate organic, i.e., formal processes occur within the work of art which correspond to the natural organic tendencies in man, and permit him, in aesthetic perception, to flow uninhibitedly with his inner feeling of vitality, with his inner need for activity, into the felicitous current of this formal happening. ${ }^{20}$ 
The general thrust of Worringer's argument is the demonstration that the foundations of representational art, which was reaching its ultimate peak in the Antique and Renaissance epochs, is a subjective psychic attunement to the other in nature, a private process through which we find ourselves "in harmony with the cosmic flux of beings out there in the natural world". This does not only explain intellectual currents like the English Romantics, but, in fact, extends to all known and unknown world-historical spiritual movements aiming at bridging the gap between man and nature. The dualistic opposition itself between the 'person' and the 'material-living whole' (nature), to be found, for example, in religion and mysticism, is not accidental, for the concept of naturalism, as a worldview, does not make sense without that characteristic pervasive underlying striving toward the nonself via empathy. The love of animals and plants, advocated by certain spiritual sects, can always be traced back to some sort of emphatic identification with a non-subjective object [168]. But Hegelianism had just gone as far as could be reached in this regard by simply annihilating the object and the subject in the Absolute [70], or the cosmic selfKnowing awareness of thinking as such (Hegel [166] misunderstanding Spinoza [132]? Emerson [169] misunderstood by Nietzsche [151]?) Empathy grounds naturalism though, metaphysically speaking, naturalism claims Being as essentially dwelling beyond the contingent boundaries of the empirical ego. But this is simply not true: Naturalism is an aesthetic theory that is metaphysically false precisely for the reason that it is grounded on an unambiguous personalistic bias toward the empathy of the ego-pole with the non-ego (material nature) and other egos. ${ }^{21}$

But if naturalism is not imitation because the former is based on empathy (while the latter is not), then why should naturalism fall out of consideration? Worringer had something both old and new to say. He was out to remind his readers about the preWestern oriental art tradition that had not been assimilated to the transcendent religions of Judaism and Christianity. In contrast to empathy, the urge to consolidate and engage the process of abstraction in nature is what defines the anti-naturalistic dimension of that unique and continuous non-Western artistic experience, which had reached one of its peaks in Ancient Egypt:

To this concept of naturalism we contrasted the concept of style. This concept is highly elastic in its use and meaning ... Nevertheless, we shall endeavour to give the concept a clear interpretation derived from the facts of the case. Since we recognize as only secondary the role played by the natural model in the work of art, and assume an absolute artistic volition, which makes itself the master of the external as mere objects to be made use of, as the primary factor in the process that gives birth to art, it stands to reason that we cannot accept the aforesaid popular interpretation of the concept of style; since this involves, as the primary and crucial factor, the endeavour to render the natural model ... Indeed, it is our intention, having associated the concept of naturalism with the process of empathy, to associate the concept of style with the other pole of the human artistic experience, namely with the urge to abstraction. ${ }^{22}$

Although we will not adopt the terminology proposed above by associating 'style' with abstraction, Worringer's basic thesis remains correct. To understand the theory of postnaturalistic art we are advocating here, one must realize the absence in the creative act itself of not only empathy, but also the irrelevance of all psychological motifs in general. Dilthey, for one example, has not understood this point correctly, even while critical of the gardenvariety naturalism he found in the mainstream materialistic aesthetic theories so popular toward the end of the nineteenth century. On the other hand, Artaud did exorcise the psychic by formulating an original program for the aesthetics of nature completely based on bodies without organs and nonhuman images [2,22].

Art is not only nonrepresentational, but even its non-figurative order and act cannot and should not be linked in a fundamental way to any internal "feeling" or "sensations". In his influential text Concerning the Spiritual in Art [172], Kandinsky, one of the founders of Abstract Expressionism, attempted to facilitate the experiential content of abstract paintings 
by vaguely referring us to some 'inner necessity' felt by the artist while constructing his work. This term was not designed to generate mystical connotations, but rather implies that the creator expresses his internal states of wonder or excitement in a more direct, and hence "pure", manner than when devising a plan based on some objective models found in nature. In such case, abstract art, or as Kandinsky prefers to call it, "concrete art", becomes the most sublime form of art because it avoids traversing any direct or indirect route that would eventually lead to a position forcing the artist to disclose his inner private feelings.

But we don't know why should Abstract Expressionism be considered different from figurative art if both are to be grounded in psychological motifs. The fact that representational artworks operate by empathy, while abstraction (via expressionism) does not, would then require the ontological theorem that there is a fundamental difference between empathy and expression. But since most abstract artists (including Kandinsky and Picasso) have not been philosophically sophisticated enough to realize the identity of expression and empathy as variations on one and the same psychological substrate, then the attempt to establish a fundamental divide between figurative and non-figurative art founders at this conceptional level: There is no essential difference between, say, abstract and literal landscapes, if the purpose is to communicate an internal psychic image. Empathy is a motive for connecting with natural objects; it serves as the prime mover in this respect, while the expressive urge finds its ultimate satisfaction by securing this empathetic bond on a solid formal ground, the artwork itself.

If the expressive drive is not satiated through figurative means, then the "concrete" treatment of the subject matter announced by Kandinsky and Abstract Expressionism finds its resolution in the formal possibility of manipulating and controlling the structural aspects of the material world. We are far away from imitation now, but certainly not as far as we must be from naturalism. Abstract Expressionism is a progressive movement in its abstract element, but had already become reactionary by devoting its energy to the problems of "expressions" (understood psychologically). This applies not only to painting, but to all art forms that can be treated by the broad methodological approach propounded by the expressionists. True, we find post-modernists working "abstractly", but while conceiving their work psychologically, that is, internally, subjectively, personalistically, etc. That does not apply to everybody, but it is certainly the case with almost everyone in mainstream art nowadays (with few exceptions, see Section 9). The subjective expression conceived internally is a private object sealed off from the public sphere; it comes "naturally" to the interior psychic world of the artist, after which it realizes its exterior concrete materialization in one physical form or another. Such process does not follow established customary rules of discourse, like representation or figuration, but quickly erects its own authoritarian regime of signs, laws of literacy, and rules of metaphors, collectively organizing, shaping, and controlling the vast sum total of everything that could be formally manipulated in the art world. Expressionism represents, then, a "purification" of High Modernism by which the representational Cartesian Subject finds is most natural abode in the history of art. As in the colloquial formula 'Marxism is capitalism gone mad', we find the parallel proposition 'expressionism is representationalism gone mad'.

So what exactly is going on here? Are not those expressionists supposed to be the high priests of revolutionary modernism, the fearless destroyers of the naturalist cult and its traditions and customs? The answer is not very simple, but the various outcomes of the entire investigation carried out in this article point toward a turning twist in the history of art. There appears to be no possible further development in line with the previously established methods of artists working in conjunction with a caring, maternal society. Art can no longer by consumed by the public, and it is certainly not to be conceived with the public gaze in sight. And the discussion does not repeat the trite cliche of "art for art's sake", which was rightly declaimed before as a form of decadence. The problem facing art now is much more complex and dangerous. While it does not yet threaten the very definition of what counts as art or not, it singles out a mode of inquiry in philosophical aesthetics that, right from the beginning, leaves behind all known traditional 
domains. Only a very thin line separates abstract, post-Cartesian, post-naturalistic art from falling back into Cartesianism and naturalism, and that line is drawn by the subtle inflections of expressionism as a worldview. Although, in agreement with Worringer, abstraction has always been a force working invisibly inside civilization, it has been recently suppressed and repressed on a massive scale by capitalism and hence became one of its arch-enemies [147]. An abstraction that is non-expressionistic is something very hard to define, even in Worringer's writings, which, as will be discussed somewhere else, remain operating with a mathematical conception of the world that is in essence Cartesian.

\section{Remarks on Posthumanism and Aesthetics}

Before, moving on to the conclusion, it is probably helpful to pause for a while to reflect on the potential relation between the program of the aesthetics of nature discussed above, and the nowadays quasi-popular direction in philosophy, cultural theory, and technology called posthumanism, e.g., see some possible formulations given in places like [173-175]. The goal is to avoid a possible confusion between our discussion and the numerous existing definitions and meanings associated with the so-called "posthumanist turn" in contemporary culture. Because the theory of the aesthetics of nature in general, and especially the version presented here, has been consistently amplifying the nonhuman aspect of being and becoming, mainly via its organic connection with Nature, one possible question at this point is whether what we mean by the nonhuman has a direct relevance to mainstream currents of posthumanism. To answer this question, we first note that posthumanism is a controversial subject, where the term itself does not enjoy a standard definition sanctioned by a majority of thinkers and practitioners; various shades of meaning and significations are often attributed to the term, which, not infrequently, are sometimes even mutually contradictory. For example, in one place one may find posthumanism understood as an approach within cultural theory, with its main goal being to de-emphasize and downplay the centrality of the human dominion of cultural production. Other theories see in this direction an attack on humanism in general, and idealism in particular. Yet a third series of interpretations of posthumanism revolve around the popular theme of the potential replacement of humans by posthuman machines (robots, cyborgs, androids, AI-assisted agents, etc). None of these meanings exactly match our sense of the term nonhuman. Nor any available posthumanist attitude fully succeed in explicating the precise significance of the aesthetics of nature when it comes to its relation with the human pole. We have no interest here in surveying the available theories of posthumanism, nor are we going to develop in details a proposal to relate what we perceive as the main currents of the posthuman society with aesthetic theory. ${ }^{23}$ However, few suggestions and explanations are in order.

For us, the nonhuman should be understood philosophically, not culturally, where our main frame of reference is the particular approach developed by postmodernist thinkers such as Simondon [81,82], Guattari [37] and Deleuze [22] in their life-long quest to combat Idealism, basically in line with the earlier critiques of western metaphysics supplied by Nietzsche and Heidegger. The nonhuman, then, means the trans-individual element of nature that envelops the already individuated human by reaching back to that global ubiquitous field of creative production in nature, what Simondon termed the preindividual [81], and Deleuze and Guattari dubbed Chaos [131]. This is probably related to subsequent directions in posthumanism, yet it is a distinct ontological concept that can stand on its own even without being necessarily entangled with the terms and the cultures associated with the posthumanist approach to contemporary life. In the movement of the human individual toward the trans-individual, there is a process of "return to nature" that is not fundamentally based on the special viewpoint of the human ego or the Cartesian-Kantian subject, as we found in the naturalism of the Romantic movement for instance. Instead, the nonhuman element of the aesthetics of nature, in agreement with Guattari, is an embedding of both the existing and future humans into the sociopolitical field of nature, which is the most fundamental structural component of the system of both human and nonhuman 
experience [22]. Art, then, can become a method for resisting idealist coding techniques, where the human subject has been forced to conform to the prevailing orders of discourses, such as that of the bourgeoisie or capitalism [20]. Even in more recent times, posthumanism has been approached as a method to emancipate the individual from the repressive mechanisms of the dominant social field [176].

So why would an artist or philosopher need to develop an aesthetics in a posthuman world? The various answers given before to questions of this sort mostly point toward the ethico-political dimension of the artistic experience. According to Guattari for example, all art is political $[19,20,37]$. One is always immersed into the sociopolitical field of everyday experience [177]. But for us there is more than politics, or even onto-politics as in Deleuze and Guattari $[85,128,178]$. If we fundamentally link the artistic process of creative art production with the process of ontogenesis in nature, then art, exactly like mathematics, becomes a means to probe the inner structure of reality. This is the deep sense of our claim that postmodern mathematics and postmodern art will eventually converge into each other at some point in the future because they are both based on a fundamental commitment to one program of the philosophy of nature or another. On the other hand, the ethical dimension of art and aesthetics continues to be relevant in the posthumanist context because of the specific meaning we have in mind for what constitutes a posthuman as such. The latter sense comes from concepts such as the Superman in Nietzsche [31], the Self in Jung [154,155], the Future Ones in Heidegger [179], the Transindividual in Simondon [81], and the Self sliding through lines of flights in Guattari and Deleuze [21,37,38]. In all such semantic shadings, the key concept is the futurist or yet-to-come structure of the posthuman, who is projected to carry a higher load in the ethical education of the human society. A posthuman society in this sense is essentially developed within a concept of art understood metaphysically, as, for example, in Hölderlin's and Wagner's visions of a Greek revival and rejuvenation of contemporary cultures. In direct contrast to Plato's anti-art attitude, artists, according to this view, are to be elevated to the highest level in a future society transcending the human and the humanist dimension of experience. It is curious to see how this shared belief in the ethico-political dimension of the posthuman cuts through extremely diverse range of modern and postmodern thinkers alike, going through Hölderlin, Schopenhauer, Wagner, Nietzsche, cruising through Bakhtin, Heidegger, Jung, Pessoa, and crossing into Simondon, Deleuze, Foucault, and Guattari. A majority of those thinkers believed that it is the artist who is best equipped to deal with the problem of future posthumanity. In our opinion, this anti-Platonic theory of art is a major trait of the program of the aesthetics of nature and its relation with posthumanism, and is here to stay. A Full explication of the topic will be given somewhere else.

\section{Conclusions}

The view advocated here, that of the aesthetics of nature, exemplified by the works of Antonin Artaud and others, required that we develop a specific body of ontological concepts suitable for a post-human, post-subjective future society. Concepts of nonpersonal experiential fields and nonhuman images were outlined and developed in connection with Artaud's ontology of the process of creative art production and the relation between art and society. The view of art within the philosophy of nature was termed the aesthetics of nature, setting the latter against natural aesthetics. Dilthey's and Worringer's writings were examined to understand the transition from natural aesthetics to the Artaudian framework of the aesthetics of nature. The analysis by Worringer pointed out expressionism as a philosophical movement transcending naturalism by way of abstraction. We criticised this attitude, suggesting that expressionism is still not far enough from idealism. The ontology of art production sketched out briefly above aspires to new modes of artistic experience that go beyond expressionism as such, say a non-expressionist position drawn from within a universal philosophy of nature, such as abstract materialism, non-expressionist abstract art, and other forms of art. 
Non-expressionistic abstraction is a politico-philosophical counter-force against the domination of all kinds of signs and coding, and certainly it is a post-metaphysical movement in the tradition of Nietzsche and Heidegger. Some of the artists whom we consider post-expressionist abstract-materialists, for example, Hans Hofmann [180-182] and Jackson Pollock [183] in abstract painting, Beckett [184] and Cormac McCarthy $[185,186]$ in literature, Stan Brakhage $[187,188]$ and Werner Herzog $[189,190]$ in film, are among those free spirits, in the Nietzschean sense of the term, who opted for carving out a unique direction of their own, often clashing with their societies, but while all working from within the aesthetics of nature worldview. Although some of them, or even all, are sometimes considered "expressionistic" (by the academic standards of the term), we believe they are not part of any identifiable mainstream current. Their work has no direct relevance to "common" problems of life and society filtered through the established traditions of Western aesthetic theories. Yet everything those artists perform and achieve appears to reconstruct, at a deeper philosophical level, the complete totality of all virtual strata of the bodies and material forces constitutive of the Real as such (which in our theory is also the Imaginary), hence-pace Heidegger-gifting us with a supreme experiment in creative destruction and production, both practiced, simultaneously, at the same ontological level of experience. The abstract machines of Deleuze and Guattari [22] are something of this sort, and so are the nomadic machines of history [191,192], mathematics [90,91,193,194], and some philosophically-oriented esoteric underground religions [195].

Funding: This research received no external funding.

Conflicts of Interest: The authors declare no conflict of interest.

\section{Notes}

1 Cf. A. Artaud, To Have Done With the Judgement of God, 1947 [2]. For background literature on the criticism of the fundamental role played in Idealism by the Cartesian subject and the ego-consciousness pole, see Nietzsche's notes [12,13], Heidegger's numerous lecture courses, e.g., [14-18], and Guattari's various critiques of subjectivity in texts such as $[19,20]$.

2 See in particular Heidegger's very thorough and rigorous critique of Kant's transcendental aesthetics for more technical information on how the concept of objecthood is founded on the Cartesian subject $[14,16,23,24]$.

3 Auden's poem September 1, 1939 [25].

4 There is already a significant secondary literature covering various other aspects of their philosophies of art, e.g., see [33-36].

5 Cf. Section 5.

6 Heidegger's neglect of Stoicism, Epicureanism, and Neoplatonism, is well known but hard to understand or justify. Those ancient thinkers approached the concept of Nature and her relation to the human lifeworld in a mode that is essentially distinct from both Plato and Aristotle, though based on Platonic-Aristotelian notions. Heidegger either simply ignores or downplays this very rich and profound tradition of Late Antiquity, early Christianity. Fortunately, postmodern philosophers and thinkers, such as Althusser [57], Deleuze [58], and Foucault [59-61], while all were influenced by Heidegger at some point, either directly or indirectly, have nevertheless re-engaged with the topic of post-Idealistic modes of subjectivity rooted in the "pagan" Stoic, Epicurean, Pyrrhonist, and Cynical methods of living characteristic of Late Antiquity. It appears to me that Heidegger's motivation behind his neglect's of these post-Aristotelian bodies of reflections on nature, art, and beauty, is that somehow he saw all of them as essentially variations on the same Aristotelian structure of being-as-presence (substance ontology, idealism, Cartesianism, etc.) [16].

7 It is sometimes argued that Hegel's philosophy of nature is an essential advance beyond Descartes and Kant, effectively breaking away with the Cartesian subject. For example, Frederick Engels famously advocated a materialistic ontology of nature based on an interpretation of Hegel as an anti-idealist thinker [62]. Nevertheless, we agree with Heidegger's interpretation of Hegel's ontology [63-65] as essentially a continuation of Idealism since the basic process of the Hegelian concept of experience is modeled after the introspective mechanism of phenomenological seeing enacted by a knowing subject as pioneered by Fichte's researches [66,67], which forms the foundations of Hegel's system. See also the fundamental criticism of the idea that Marxism is a Hegelian philosophy advanced by Althusser [68]. In terms of Hegel's philosophy of art, and not unlike his philosophy of history, we find the aesthetic discourse [69] to be entirely based on the Hegelian system of fundamental ontology as was fully developed in the Larger Logic [70].

$8 \quad$ Dilthey [71], page 45.

9 As the reader may have already guessed, we are critical of this view of founding aesthetic theory on the human subject. Our criticism is based on, and motivated by, several earlier comprehensive and rigorous attacks on Idealism advanced by 
Nietzsche [12,13,29,73], Bergson [74,75], Simmel [50], Russell [76-78], Heidegger [16,79,80], Simondon [81,82], Whitehead [83], Deleuze [58,84], Guattari [19,20,37,85], Foucault [86-89], Althusser [68], Serres [90,91].

For a scathing critique of this Idealist theory of the psyche, best exemplified by Freud and Lacan, see Deleuze and Guattari's various related texts [19-22,104].

Though sometimes both image and fantasy can be studied by similar phenomenological methods [111]. Deleuze approached the relation between image and phantasm using poststructuralist, hence non-phenomenological, methods [84].

Because in the philosophy of nature the subject is produced in and through nature, e.g., see the various processes of subjectification, subjectivization, subjection, etc, often discussed in the social ontologies of Deleuze, Guattari, and Foucault [19-22,38,61,87,112-115].

While a detailed discussion is not within the scope of this article, Deleuze had written extensively on the topic of the typology of art-forms, art media, and their organic connection with a comprehensive background ontology of nature. For example, see the texts on cinema [123,124], literature [125-129], painting [130]. These writings are relevant to our main theme here, even while we may disagree with some of the technical details of Deleuze's interpretations of art. The key theoretical concept can be found in the last (and possibly most important) book by Deleuze and Guattari, What is Philosophy? [131], which defines art as the process of the production of affects. In Deleuze's ontology, affects are understood as in Spinoza's system [132], that is, as natural, but not subjective processes [133].

Some of the key figures behind the emphasis on the psychological approach to aesthetic theory, an orientation that continues to be popular nowadays, especially in the Anglo-American literature, include the already mentioned Helmholtz and Wundt, but also the Gestalt school, most notably Arnheim [142]. In parallel to this cognitive school of aesthetic theory, the sociological school is also very prominent, including influential figures such as Adorno [100], Horkheimer [143], Benjamin [93], Eagleton [144], Jameson $[145,146]$. It is curious to note that most of the adherents of the latter school, i.e., the social theory camp, tend to be more or less affiliated with some form of Hegelianism. On the other hand, postmodernist thinkers who engaged deeply with art and aesthetics, such as Baudrillard [117,147], Guattari [37], and Deleuze [128], are visibly and openly anti-Hegelian. Dilthey [71], page 187.

Bakhtin's book-length manuscript on Goethe was destroyed by a German raid during World War II. Luckily for us, a very dense and substantial fragment survived, published in the collection [10].

Dilthey [71], page 250.

Artaud [2], page 291.

Ibid., our italics.

Worringer [167], pages 32-33.

Husserl, the last great Kantian, will make the theme of empathy very prominent in his later philosophical writings (e.g., see [170] and other unpublished manuscripts), yet while still blindly insisting that he is "not doing psychology". Although his use of empathy in the analysis of the genesis of intersubjective experience [171] is interesting, in our opinion it is not fundamentally ontological, and hence remains within the parameters of the Kantian subject-based project metaphysics. Worringer [167], pages 33-34. Translation slightly edited.

Nevertheless, I may have more on common with the second approach to posthumanism mentioned above, mainly the philosophical formulation where posthumanism is viewed as "anti-humanism" (a bad term in my opinion). That is, I agree with the proponents of this framework that posthumanism might be best understood, at least in part, as $a$ stage in the grand criticism of idealism and related human-centered dominant traditions of western of metaphysics, e.g., as found in the writings of Nietzsche, Heidegger, Simondon, Deleuze, Foucault, and Guattari.

\section{References}

1. Aristotle. Poetics; Oxford University Press: Oxford, UK, 2013.

2. Artaud, A. Antonin Artaud: Selected Writings; University of California Press: Berkeley, CA, USA, 1988.

3. Eisenstein, S. The Film Sense; Harcourt, Brace: New York, NY, USA, 1947.

4. Eisenstein, S. Film Form: Essays in Film Theory; Harcourt, Brace: New York, NY, USA, 1949.

5. $\quad$ Eisenstein, S. Selected Works, Volume 2: Towards a Theory of Montage-1937-40; BFI Pub. Indiana University Press: London, UK; Bloomington, IN, USA, 1988.

6. Eisenstein, S. Nonindifferent Nature: Film and the Structure of Things; Cambridge University Press: Cambridge, NY, USA, 1987.

7. Bakhtin, M.M. The Dialogic Imagination: Four Essays; University of Texas Press: Austin, TX, USA, 1981.

8. Bakhtin, M.M. Problems of Dostoevsky's Poetics; University of Minnesota Press: Minneapolis, MN, USA, 1984.

9. Bakhtin, M.M. Rabelais and His World; Indiana University Press: Bloomington, IN, USA, 1984.

10. Bakhtin, M.M. Speech Genres \& Other Late Essays; University of Texas Press: Austin, TX, USA, 1986.

11. Bakhtin, M.M. Art and Answerability: Early Philosophical Essays; University of Texas Press: Austin, TX, USA, 1990.

12. Nietzsche, F. The Will to Power: Selections from the Notebooks of the 1880s; Penguin Classics; Penguin Books: London, UK, 2017.

13. Nietzsche, F. The Will to Power; Random House: New York, NY, USA, 1967.

14. Heidegger, M. What is a Thing?; H. Regnery Co: Chicago, IL, USA, 1968.

15. Heidegger, M. History of the Concept of Time: Prolegomena; Indiana University Press: Bloomington, IN, USA, 1985. 
16. Heidegger, M. The Basic Problems of Phenomenology; Indiana University Press: Bloomington, IN, USA, 1988.

17. Heidegger, M. Nietzsche: Volume 1 and 2 (Vol. 1: The Will to Power as Art, Vol. 2: The Eternal Recurrence of the Same); HarperSanFrancisco: San Francisco, CA, USA, 1991.

18. Heidegger, M. Nietzsche: Volume 3 and 4 (Vol. 3: The Will to Power as Knowledge and as Metaphysics; Vol. 4: Nihilism); HarperSanFrancisco: San Francisco, CA, USA, 1991.

19. Guattari, F. The Anti-Oedipus Papers; Semiotext(e) Distributed by MIT Press: New York, NY, USA; Cambridge, NY, USA; Mass, MI, USA, 2006.

20. Guattari, F. The Machinic Unconscious: Essays in Schizoanalysis; Semiotext(e) Distributed by the MIT Press: Los Angeles, CA, USA; Cambridge, NY, USA; Mass, MI, USA, 2011.

21. Deleuze, G.; Guattari, F. Anti-Oedipus: Capitalism and Schizophrenia; University of Minnesota Press: Minneapolis, MN, USA, 1983.

22. Deleuze, G.; Guattari, F. A Thousand plateaus: Capitalism and Schizophrenia; University of Minnesota Press: Minneapolis, MN, USA, 1987.

23. Heidegger, M. Kant and the Problem of Metaphysics; Indiana University Press: Bloomington, IN, USA, 1962.

24. Heidegger, M. The Question Concerning the Thing: on Kant's Doctrine of the Transcendental Principles; Rowman \& Littlefield International Ltd: London, UK; Lanham, MD, USA, 2018.

25. Auden, W.H. Selected Poems; Vintage International: New York, NY, USA, 2007.

26. Nietzsche, F. The Birth of Tragedy and Other Writings; Cambridge University Press: Cambridge, UK; New York, NY, USA, 1999.

27. Nietzsche, F. Selected Letters of Friedrich Nietzsche; Hackett Pub: Indianapolis, Indiana, 1996.

28. Nietzsche, F. Untimely Meditations; Cambridge University Press: Cambridge, NY, USA, 1997.

29. Nietzsche, F. Unpublished Writings from the Period of Unfashionable Observations; Stanford University Press: Stanford, CA, USA, 1999.

30. Nietzsche, F. Writings from the Early Notebooks; Cambridge University Press: Cambridge, UK; New York, NY, USA, 2009.

31. Nietzsche, F. Thus Spoke Zarathustra: A Book for All and None; Cambrige University Press: Cambridge, NY, USA, 2006.

32. Pessoa, F. The Book of Disquiet; New Directions Publishing Corporation: New York, NY, USA, 2017.

33. Dries, M.; Kail, P.J.E., Eds. Nietzsche on Mind and Nature; Oxford University Press: Oxford, UK, 2015.

34. Young, J. Friedrich Nietzsche: A Philosophical Biography; Cambridge University Press: Cambridge UK; New York, NY, USA, 2010.

35. Carroll, N. Eisenstein's Philosophy Of Film. In Camera Obscura, Camera Lucida; Amsterdam University Press: Amsterdam, The Netharlands, 2003; pp. 127-146.

36. Donals, M. Mikhail Bakhtin: Between Phenomenology and Marxism; Cambridge University Press: Cambridge, UK; New York, NY, USA, 1994

37. Guattari, F. Chaosmosis: An Ethico-Aesthetic Paradigm; Power Publications: Sydney, 1995.

38. Guattari, F. Lines of Flight: For Another World of Possibilities; Bloomsbury Academic, an Imprint of Bloomsburg Publishing Pl: London, UK, 2016.

39. Cassirer, E. The philosophy of the Enlightenment; Princeton classic editions; Princeton University Press: Princeton, NJ, USA, 2009.

40. Zubiri, X. Fundamental Problems of Western Metaphysics; University Press of America: Lanham, MD, USA, 2010.

41. Gadamer, H. Truth and Method; Continuum: London, UK; New York, NY, USA, 2004.

42. Dilthey, W. Selected Works, Volume IV: Hermeneutics and the Study of History; Princeton University Press: Princeton, NJ, USA, 2010.

43. Dilthey, W. Selected Works, Volume III: The Formation of the Historical World in the Human Sciences; Princeton University Press: Princeton, NJ, USA, 2010.

44. Dilthey, W. Selected Works, Volume I: Introduction to the Human Sciences; Princeton University Press: Princeton, NJ, USA, 1989.

45. Husserl, E. Logical Investigations: Vol. 1; Routledge, Taylor \& Francis Group: London, UK; New York, NY, USA, 2001.

46. Husserl, E. Logical Investigations: Vol. 2; Routledge, Taylor \& Francis Group: London, UK; New York, NY, USA, 2001.

47. Simmel, G. On Individuality and Social Forms: Selected Writings; University of Chicago Press: Chicago, IL, USA; London, UK, 1971.

48. Simmel, G. Simmel on Culture: Selected Writings; Sage Publications: London, UK; Thousand Oaks, CA, USA, 1997.

49. Simmel, G. The Philosophy of Money; Routledge: Abingdon, UK; New York, NY, USA, 2011.

50. Simmel, G. The View of Life: Four Metaphysical Essays with Journal Aphorisms; University of Chicago Press: Chicago, IL, USA, 2015.

51. Feyerabend, P. Philosophy of Nature; Polity Press: Cambridge, UK; Medford, MA, USA, 2018.

52. Heidegger, M. Phenomenological Interpretations of Aristotle: Initiation Into Phenomenological Research; Indiana University Press: Bloomington, IN, USA, 2001.

53. Heidegger, M. Aristotle's Metaphysics (on the Essence and Actuality of Force); Indiana University Press: Bloomington, IN, USA, 1995.

54. Heidegger, M. Plato's Sophist; Indiana University Press: Bloomington, IN, USA, 2003.

55. Plotinus. The Enneads; Cambridge University Press: Cambridge, UK, 2018.

56. Proclus. The Commentaries of Proclus on the Timaeus of Plato: In Five Books, Containing a Treasury of Pythagoric and Platonic Physiology, Translated by Thomas Taylor; CreateSpace: Scotts Valley, CA , USA, 2012.

57. Althusser, L. Philosophy of the Encounter: LATER Writings (1978-87); Verso: London, UK; New York, NY, USA, 2006.

58. Deleuze, G. Difference and Repetition; Columbia University Press: New York, NY, USA, 1994.

59. Foucault, M. The History of Sexuality II: The Use of Pleasure; Vintage Books: New York, NY, USA, 1990.

60. Foucault, M. The History of Sexuality III: The Care of the Self; Vintage Books: New York, NY, USA, 1988.

61. Foucault, M. Ethics: Subjectivity and Truth; New Press: New York, NY, USA, 1997.

62. Engels, F. Dialectics of Nature; Wellred: London, UK, 2012. 
63. Heidegger, M. Hegel's Phenomenology of Spirit; Indiana University Press: Bloomington, IN, USA, 1994.

64. Heidegger, M. Hegel; Indiana University Press: Bloomington, IN, USA, 2015.

65. Heidegger, M. Hegel's Concept of Experience: With a Section from Hegel's Phenomenology of Spirit; Harper \& Row: San Francisco, CA, USA, 1989.

66. Fichte, J. Introductions to the Wissenschaftslehre and Other Writings: 1797-1800; Hackett Pub. Co: Indianapolis, IN, USA, 1994.

67. Fichte, J. The Science of Knowing: J.G. Fichte's 1804 Lectures on the Wissenschaftslehre; State University of New York Press: Albany, NY, USA, 2005.

68. Althusser, L. The Humanist Controversy and other Writings: 1966-67; Verso: London, UK; New York, NY, USA, 2003.

69. Hegel, G. Aesthetics: Lectures on Fine Art; Clarendon Press: Oxford, UK, 1975.

70. Hegel, G. The Science of Logic; Cambridge University Press: Cambridge, UK; New York, NY, USA, 2010.

71. Dilthey, W. Selected Works, Volume V: Poetry and Experience; Princeton University Press: Princeton, NJ, USA,1985.

72. Schelling, F. The Philosophy of Art; University of Minnesota Press: Minneapolis, MN, USA, 1989.

73. Nietzsche, F. Writings from the Late Notebooks; Cambridge University Press: Cambridge, UK; New York, NY, USA, 2003.

74. Bergson, H. Time and Free Will: An Essay on the Immediate Data of Consciousness; Harpars: New York, NY, USA, 1960.

75. Bergson, H. Matter and Memory; Zone Books: New York, NY, USA, 1988.

76. Russell, B. A critical Exposition of the Philosophy of Leibniz; Routledge: London, UK, 1992.

77. Russell, B. The Philosophy of Logical Atomism; Open Court: LaSalle, IL, USA, 1985.

78. Russell, B. My Philosophical Development; Spokesman: Nottingham, UK, 2007.

79. Heidegger, M. Being and Time; HarperPerennial/Modern Thought: New York, NY, USA, 2008.

80. Heidegger, M. Contributions to Philosophy: Of the Event; Indiana University Press: Bloomington, IN, USA, 2012.

81. Simondon, G. Individuation in Light of Notions of Form and Information; Part I; Univ of Minnesota Press: Minneapolis, MN, USA, 2020

82. Simondon, G. Individuation in Light of Notions of Form and Information; Part II; Univ of Minnesota Press: Minneapolis, MN, USA, 2020.

83. Whitehead, A. The Concept of Nature: The Tarner Lectures Delivered in Trinity College, November 1919; Cambridge University Press: Cambridge, UK, 2015.

84. Deleuze, G. Logic of Sense; Bloomsbury Academic: London, UK, 2015.

85. Guattari, F. Chaosophy: Texts and Interviews 1972-1977; Semiotext(e: Los Angeles, CA, USA, 2009.

86. Foucault, M. Language, Counter-Memory, Practice: Selected Essays and Interviews; Cornell University Press: Ithaca, NY, USA, 1977.

87. Foucault, M. Power/Knowledge: Selected Interviews and Other Writings (1972-1977); Pantheon Books: New York, NY, USA, 1980.

88. Foucault, M. The Archaeology of Knowledge; Pantheon Books: New York, NY, USA, 1972.

89. Foucault, M. The Order of Things: An Archaeology of the Human Sciences; Vintage Books: New York, NY, USA, 1994.

90. Serres, M. Genesis; University of Michigan Press: Ann Arbor, MI, USA, 1995.

91. Serres, M. Hermes: Literature, Science, Philosophy; Johns Hopkins University Press: Baltimore, MD, USA, 1982.

92. Jonas, H. The Phenomenon of Life: Toward a Philosophical Biology; Northwestern University Press: Evanston, IL, USA, 2001.

93. Benjamin, W. The Work of Art in the Age of Its Technological Reproducibility, and Other Writings on Media; The Belknap Press of Harvard University Press: Cambridge, MA, USA, 2008.

94. Marx, K. Capital: A Critique of Political Economy; Penguin Books in association with New Left Review: London New York, NY, USA, 1978; Volume 1.

95. Marx, K. Grundrisse: Foundations of the Critique of Political Economy (Rough Draft); Penguin Books in association with New Left Review: London, UK; New York, NY, USA, 1993.

96. Heidegger, M. Poetry, Language, Thought; Perennical Classics: New York, NY, USA, 2001.

97. Heidegger, M. The Question Concerning Technology, and Other Essays; HarperCollins Publishers: New York, NY, USA, 2013.

98. Althusser, L. Reading Capital: The Complete Edition; Verso, the Imprint of New Left Books: London, UK; New York, NY, USA, 2015.

99. Lukacs, G. The Ontology of Social Being, Volume 2: Hegel; Merlin Press: London, UK, 1978.

100. Adorno, T. Aesthetic Theory; University of Minnesota Press: Minneapolis, MN, USA, 1997.

101. Adorno, T. Negative Dialectics; Continuum: New York, NY, USA, 1983.

102. Marcuse, H. Hegel's Ontology and the Theory of Historicity; MIT Press: Cambridge, MA, USA, 1987.

103. Heidegger, M. Introduction to Phenomenological Research; Indiana University Press: Bloomington, IN, USA, 2005.

104. Guattari, F. Schizoanalytic Cartographies; Bloomsbury: London, UK; New York, NY, USA, 2013.

105. Hegel, G. The Phenomenology of Mind; Dover Publications: Mineola, NY, USA, 2003.

106. Althusser, L. On Ideology; Verso: London, UK; New York, NY, USA, 2008.

107. Whitehead, A. Process and Reality: An Essay in Cosmology; Free Press: New York, NY, USA, 1978.

108. Uexk'ull, J. Theoretische Biologie; Springer: Berlin/Heidelberg, Germany, 1928.

109. Bateson, G. Steps to an Ecology of Mind; University of Chicago Press: Chicago, IL, USA, 2000.

110. Girard, R. Mimesis and Theory: Essays on Literature and Criticism, 1953-2005; Stanford University Press: Stanford, CA, USA, 2008.

111. Sartre, J.P. The Imaginary: A Phenomenological Psychology of the Imagination; Routledge: New York, NY, USA, 2010.

112. Foucault, M. The Hermeneutics of the Subject: Lectures at the Collége de France, 1981-1982; Picador: New York, NY, USA, 2006. 
113. Foucault, M. The Birth of Biopolitics: Lectures at the Collége de France, 1978-79; Palgrave Macmillan: Basingstoke, UK; New York, NY, USA, 2008.

114. Foucault, M. Subjectivity and Truth: Lectures at the Collége de France, 1980-1981; Palgrave Macmillan: London, UK, 2017.

115. Deleuze, G. Foucault; University of Minnesota Press: Minneapolis, MN, USA, 1988.

116. Adorno, T. The Culture Industry: Selected Essays on Mass Culture; Routledge: London, UK; New York, NY, USA, 2001.

117. Baudrillard, J. Simulacra and Simulation; University of Michigan Press: Ann Arbor, MI, USA, 1994.

118. Baudrillard, J. The Consumer Society: Myths and Structures; Sage Publications Ltd: London, UK, 1998.

119. Jaspers, K. Man in the Modern Age; Routledge: London, UK, 2010.

120. Hume, D. A Treatise of Human Nature; Dover Publications: Mineola, NY, USA, 2003.

121. Deleuze, G. Empiricism and Subjectivity: An Essay on Hume's Theory of Human Nature; Columbia University Press: New York, NY, USA, 1991.

122. Uexk'uull, J. A Foray into the Worlds of Animals and Humans: With a Theory of Meaning; University of Minnesota Press: Minneapolis, MN, USA, 2010.

123. Deleuze, G. Cinema 1: The Movement-Image; University of Minnesota: Minneapolis, MN, USA, 1986.

124. Deleuze, G. Cinema 2: The Time-Image; University of Minnesota: Minneapolis, MN, USA, 1986.

125. Deleuze, G.; Guattari, F. Kafka: Toward a Minor Literature; University of Minnesota Press: Minneapolis, MN, USA, 1986.

126. Deleuze, G. Masochism; Zone Books Distributed by the MIT Press: New York, NY, USA; Cambridge, MA, USA, 1989.

127. Deleuze, G. Proust and Signs; University of Minnesota Press: Minneapolis, MN, USA, 2000.

128. Deleuze, G. Essays Critical and Clinical; University of Minnesota Press: Minneapolis, MN, USA, 1997.

129. Deleuze, G. Desert Islands and Other Texts: 1953-1974; Semiotext(e) Distributed by MIT Press: Los Angeles, CA, USA; Cambridge, MA, USA, 2004.

130. Deleuze, G. Francis Bacon: The Logic of Sensation; University of Minnesota Press: Minneapolis, MN, USA, 2004.

131. Deleuze, G.; Guattari, F. What is Philosophy?; Columbia University Press: New York, NY, USA, 1994.

132. Spinoza. Ethics; Penguin Books: London, UK; New York, NY, USA, 1996.

133. Deleuze, G. Expressionism in Philosophy: Spinoza; Zone Books Distributed by MIT Press: New York, NY, USA; Cambridge, MA, USA, 1990

134. Locke, J. An Essay Concerning Human Understanding; New York Penguin Books: London, UK, 1997.

135. Berkeley, G. Principles of Human Knowledge; and, Three Dialogues; Oxford University Press: Oxford, UK; New York, NY, USA, 1996.

136. Kant, I. Critique of judgement; Oxford University Press: Oxford, UK; New York, NY, USA, 2008.

137. Schiller, F. On the Aesthetic Education of Man, and, Letters to Prince Frederick Christian von Augustenburg; Penguin Books: London, UK, 2016.

138. Herder, J. Philosophical Writings; Cambridge University Press: Cambridge, UK; New York, NY, USA, 2002.

139. Dilthey, W. Selected Works, Volume II: Understanding the Human World; Princeton University Press: Princeton, NJ, USA, 2010.

140. Helmholtz, H. Science and Culture: Popular and Philosophical Essays; University of Chicago Press: Chicago, IL, USA, 1995.

141. Helmholtz, H. On the Sensations of Tone as a Physiological Basis for the Theory of Music; Dover Publications: New York, NY, USA, 1954.

142. Arnheim, R. Visual Thinking; University of California Press: Berkeley, CA, USA, 1969.

143. Horkheimer, M.; Adorno, T. Dialectic of Enlightenment: Philosophical Fragments; Stanford University Press: Stanford, CA, USA, 2002.

144. Eagleton, T. The Ideology of the Aesthetic; Blackwell: Oxford, UK; Cambridge, MA, USA, 1990.

145. Jameson, F. Marxism and Form: Twentieth-Century Dialectical Theories of Literature; Princeton University Press: Princeton, NJ, USA, 1972.

146. Jameson, F. Postmodernism, or the Cultural Logic of Late Capitalism; Duke University Press: Durham, UK, 1991.

147. Baudrillard, J. The Conspiracy of Art: Manifestos, Interviews, Essays; Semiotext(e: New York, NY, USA, 2005.

148. Leibniz, G. Philosophical Papers and Letters; D. Reidel Pub. Co: Dordrecht, The Netherlands; Boston, MA, USA, 1976.

149. Sloterdijk, P. Bubbles: Spheres Volume I: Microspherology; Semiotext(e),Semiotext(e: Los Angeles, CA, USA; South Pasadena, CA, USA, 2011.

150. Eagleton, T. Marxism and Literary Criticism; Routledge: London, UK; New York, NY, USA, 2002.

151. Nietzsche, F. The Complete Works of Friedrich Nietzsche, Volume 9: The Case of Wagner, Twilight of the Idols, The Antichrist, Ecce Homo, Dionysus Dithyrambs, Nietzsche Contra Wagner; Stanford University Press: Stanford, CA, USA, 2021.

152. Wagner, R. Wagner on Music and Drama: A Compendium of Richard Wagner's Prose Works; Da Capo Press: New York, NY, USA, 1988.

153. Silk, M.S.; Stern, J.P. Nietzsche on Tragedy; Cambridge University Press: Cambridge, UK, 2016.

154. Jung, C.G. The Red Book; W.W. Norton \& Co: New York, NY, USA, 2009.

155. Jung, C.G. The Black Books: Notebooks of Transformation (1913-1932); W.W. Norton \& Company: New York, NY, USA, 2020.

156. Jung, C.G. Nietzsche's Zarathustra: Notes of the Seminar Given in 1934-1939; Princeton University Press: Princeton, NJ, USA, 1988.

157. Jung, C.G. Symbols of Transformation: The Collected Works of C.G. Jung; Princeton University Press: Princeton, NJ, USA, 1977; Volume 5.

158. Jung, C.G. Psychiatric Studies: The Collected Works of C.G. Jung; Princeton University Press: Princeton, NJ, USA, $1970 ;$ Volume 1.

159. Jung, C.G. Modern Man in Search of a Soul; Harcourt, Brace \& World: New York, NY, USA, 1933.

160. Jung, C.G. Psychological Types: The Collected Works of C.G. Jung; Princeton University Press: Princeton, NJ, USA, 1976 ; Volume 6.

161. Lawrence, D.H. Psychoanalysis and the Unconscious and Fantasia of the Unconscious; Dover Publications: Mineola, NY, USA, 2005. 
162. Lawrence, D.H. Phoenix: The Posthumous Papers of D.H. Lawrence; Viking Press: New York, NY, USA, 1972.

163. Bermel, A. Artaud's Theatre of Cruelty; Methuen: London, UK, 2001.

164. Eagleton, T. Literary Theory: An Introduction; University of Minnesota Press: Minneapolis, MN, USA, 2008.

165. Eagleton, T. Sweet Violence: The Idea of the Tragic; Blackwell Pub: Oxford, UK; Malden, MA, USA, 2003.

166. Hegel, G. Hegel's Philosophy of Nature: Being Part Two of the Encyclopaedia of the Philosophical Sciences (1830)7; Clarendon Press: Oxford, UK; New York, NY, USA, 2004.

167. Worringer, W. Abstraction and Empathy: A Contribution to the Psychology of Style; Martino Publishing: Mansfield Centre, CT, USA, 2014

168. Cassirer, E. The Philosophy of Symbolic Forms, Volume II: Mythical Thought; Yale Univ. Press: New Haven, CT, USA, 1971.

169. Emerson, R. The Essential Writings of Ralph Waldo Emerson; Modern Library: New York, NY, USA, 2000.

170. Husserl, E. The Crisis of European Sciences and Transcendental Phenomenology: An Introduction to Phenomenological Philosophy; Northwestern University Press: Evanston, IL, USA, 1970.

171. Nenon, T.; Embree, L., Eds. Issues in Husserl's Ideas II; Kluwer Academic Publishers: Dordrecht, The Netherlands, Boston, MA, USA, 1996.

172. Kandinsky, W. Concerning the Spiritual in Art; Dover Publications: New York, NY, USA, 1977.

173. Wolfe, C. What is Posthumanism?; University of Minnesota Press: Minneapolis, MN, USA, 2010.

174. Idema, T. Stages of Transmutation: Science Fiction, Biology, and Environmental Posthumanism; Routledge: New York, NY, USA, 2019.

175. Ferrando, F. Philosophical Posthumanism; Bloomsbury Academic: London, UK, 2020.

176. Cudworth, E.; Hobden, S. The Emancipatory Project of Posthumanism; Routledge: Abingdon, UK; New York, NY, USA, 2018.

177. Deleuze, G. Letters and other Texts; Semiotext-e: South Pasadena, CA, USA, 2020.

178. Guattari, F. Soft Subversions: Texts and Interviews 1977-1985; Semiotext(e) Distributed by the MIT Press: Los Angeles, CA, USA; Cambridge, MA, USA, 2009.

179. Cantor, G. Contributions to the Founding of the Theory of Transfinite Numbers; Dover Publications: New York, NY, USA, 1955.

180. Hofmann, H. Search for the Real: And other Essays; M.I.T. Press: Cambridge, MA, USA, 1967.

181. Hoyland, J. Hans Hofmann: Late Paintings; Tate Gallery: London, UK, 1988.

182. Barnes, L., Ed. Hans Hofmann: The Nature of Abstraction; University of California Berkeley Art Museum \& Pacific Film Archive University of California Press: Berkeley, CA, USA; Oakland, CA, USA, 2019.

183. Greenberg, J.; Jordan, S. Action Jackson; Square Fish: New York, NY, USA, 2007.

184. Beckett, S. The Complete Dramatic Works; Faber and Faber: London, UK; Boston, MA, USA, 1986.

185. McCarthy, C. Outer Dark; Vintage Books: New York, NY, USA, 1993.

186. McCarthy, C. The Orchard Keeper; Vintage Books: New York, NY, USA, 1993.

187. Brakhage, S. Essential Brakhage: Selected Writings on Filmmaking; Documentext: Kingston, NY, USA, 2001.

188. Brakhage, S. Telling Time: Essays of a Visionary Filmmaker; Documentext: Kingston, NY, USA, 2003.

189. Herzog, W. Of Walking in Ice: Munich-Paris, 23 November-14 December 1974; University of Minnesota Press: Minneapolis, MN, USA, 2015.

190. Herzog, W. Fitzcarraldo: The Original Story; Fjord Press: San Francisco, CA, USA, 1982.

191. Toynbee, A. A study of History, Volume 1: Abridgement of Volumes I-VI; Oxford University Press: New York, NY, USA, 1987.

192. Toynbee, A. A Study of History, Volume 2: Abridgement of Volumes VII-X; Oxford University Press: New York, NY, USA, 1987.

193. Serres, M. Geometry: The Third Book of Foundations; Bloomsbury Academic, an imprint of Bloomsbury Publishing Plc: London, UK; New York, NY, USA, 2017.

194. Serres, M. The Birth of Physics; Rowman \& Littlefield International: London, UK; New York, NY, USA, 2018.

195. Jonas, H. The Gnostic Religion: The Message of the Alien God and the Beginnings of Christianity; Beacon Press: Boston, MA, USA, 2001. 